\title{
Selected aspects of child nutrition and the risk of obesity
}

\author{
Wybrane aspekty żywienia dzieci i ich znaczenie w etiologii otyłości
}

\section{Katarzyna Anna Majewska ${ }^{\oplus}$, Magdalena Kobylińska ${ }^{1}$, Agata Krasińska² ${ }^{\odot}$, Paulina Wais ${ }^{\circ}$, Andrzej Kędzia ${ }^{10}$}

'Department of Clinical Auxology and Paediatric Nursing, Poznan University of Medical Sciences/ Katedra Auksologii Klinicznej i Pieleggniarstwa Pediatrycznego, Uniwersytet Medyczny im. Karola Marcinkowskiego w Poznaniu ${ }^{2}$ Department of Clinical Auxology and Paediatrics Nursing, Division of Diabetology and Obesity of the Developmental Age, Poznan University of Medical Sciences/ Klinika Diabetologii i Otyłości Wieku Rozwojowego, Uniwersytet Medyczny im. Karola Marcinkowskiego w Poznaniu

CORRESPONDING AUTHOR/AUTOR DO KORESPONDENCJI:

Katarzyna A. Majewska

Katedra Auksologii Klinicznej i Pielęgniarstwa Pediatrycznego Uniwersytet Medyczny im. Karola Marcinkowskiego w Poznaniu

ul. Szpitalna 27/33, 60-572 Poznań

tel/fax +48618491265

e-mail: katarzynamajewska@ump.edu.pl

\section{STRESZCZENIE WYBRANEASPEKTY ŻYWIENIA DZIECI ICH ZNACZENIE W ENIOLOGII OTYROŚC}

Wprowadzenie. Pokarm jest podstawowym źródłem energii dla człowieka. Odpowiednio dobrany do wieku i potrzeb organizmu, zbilansowany sposób żywienia jest warunkiem dla prawidłowego wzrostu i rozwoju w dzieciństwie. Celem pracy jest przegląd aktualnego stanu wiedzy dotyczącej wpływu modelu żywienia, składu diety oraz aspektów behawioralnych związanych z przyjmowaniem pokarmu na występowanie otyłości u dzieci i młodzieży.

Podsumowanie. Zbyt duży ładunek energetyczny zawarty w pokarmie, zaburzając równowagę ustrojową pomiędzy podażą, a wydatkowaniem energii, jest częstą przyczyną występowania dziecięcej otyłości. Na tempo przyrostu masy ciała u dzieci wpływają również inne czynniki, takie jak sposób karmienia w okresie niemowlęcym, nawyki żywieniowe we wczesnych latach życia oraz szereg aspektów behawioralnych związanych z przyjmowaniem pokarmu.

Preferencje smakowe i nawyki żywieniowe kształtują się u dziecka już od pierwszych lat życia i często są kontynuowane w życiu dorosłym, zatem koniecznym elementem profilaktyki otyłości musi być szeroka wczesna edukacja obejmująca rodziców, opiekunów i same dzieci.

Słowa kluczowe: otyłość, dzieci, żywienie

\section{ABSTRACT}

\section{SELECTED ASPECTS OF CHILD NUTRITION AND THE RISK OF OBESITY}

Introduction. Food is the basic source of energy for humans. Properly matched for the age and needs of the body, a balanced diet is a condition for proper growth and development during childhood. The aim of the study is to review the current state of knowledge regarding the impact of the nutrition model, diet composition and behavioral aspects related to food intake on the occurrence of obesity in children and adolescents.

Conclusions. Too much energy charge in food, disturbing the balance between energy supply and expenditure, is a common cause of childhood obesity. The rate of weight gain in children is also affected by other factors, such as the model of feeding during infancy, eating habits in the early years of life, and a number of behavioral aspects related to food intake.

Taste preferences and eating habits are formed in a child from the first years of life and are often continued during adulthood, therefore, an essential element of obesity prevention must cover the extensive early education involving parents, caregivers and the children themselves.

Key words: obesity, children, nutrition 


\section{INTRODUCTION}

A properly balanced diet in terms of quantity and quality, as well as adapting it to the age and energy needs of the child's body, are key to ensuring optimal conditions for proper growth and development. Disturbances in the energy balance between the supply and expenditure of energy, combined with improper eating behaviors, are among the main causes of obesity in children and adolescents [1]. The aim of the study was to review the current state of knowledge regarding the impact of the nutrition model, diet composition and behavioral aspects related to food intake on the incidence of obesity in children and adolescents.

\section{Feeding infants and early development of eating habits}

There is evidence that babies breastfed are at a lower risk of developing obesity later in life than their counterparts fed with milk formulas [2-3]. Although the reasons for this phenomenon remain unclear, the important role played by the unique composition of breast milk, optimally adapted to the needs of the infant, is emphasized. There is a hypothesis that breastfed children guided by the feeling of hunger and satiety, regulate by themselves the amount and volume of meals and their timing. This has an impact on better appetite control at a later age compared to infants fed with modified milk [4]. Breast-fed babies self-regulate the consumption of nutrients and demonstrate self-control of the calorific value of the meals consumed [5].

Most formulas based on modified cow's milk contain a higher amount of protein than human milk. This phenomenon is considered to be a key factor contributing to faster weight gain in artificially fed children, also known as the early protein supply hypothesis [6]. Excess protein in the infant's diet, especially branched chain amino acids, contributes to the excessive secretion of insulin and IGF-1, activates signaling pathways of mTOR cell growth and enhances adipogenesis [7]. Scientific studies confirm that early consumption of high amounts of protein contained in milk formulas result in higher BMI in later life [8].

Another mechanism described in the literature, which is of importance in the prevention of obesity, is the composition of the intestinal microbiota of breastfed children [9]. Mother's milk is a source of natural prebiotics that stimulate the growth of lactic acid bacteria in the child's digestive system, as well as probiotics [10]. Kalliomäki et al. in their research proved that the reduced amount of Bifidobacterium bacteria between 6 and 12 months of age is related to the increased body weight at the age of 7 [11] .

The protective effect of breastfeeding against excessive body weight gain is of particular importance in children born to overweight and obese mothers, and in this group it is most pronounced [12]. Breastfeeding also appears to exert a protective effect and to reduce the risk of diseases such as hypertension, diabetes, or cardiovascular diseases later in life [13-14].

It is worth noting that it is not only the method of feeding an infant that influences the development of obesity at a later age. The child's weight in the first year of life is of great importance. Research shows that the rapid increase in body weight in the first months of life is associated with a significantly increased risk of obesity in adolescent and adults. A change in body weight during infancy may influence the risk of obesity later more than the birth weight [15].

Just after birth, babies present specific taste preferences and the ability to regulate the amount of food consumed during the day. Action of parents, preventing child self-control in this area, result in not only a change of taste preferences of the child, but also impaired innate pathways regulating hunger and satiety as well as lead to a child's consumption of excessive calories. Attentive parents, controlling the diet of the child, especially if it is loaded with family- onset obesity, can develop positive eating habits by promoting a healthy diet, appropriate for the child's age, while maintaining proper energy balance [16-19].

\section{Selected groups of foods and their importance in the context of obesity development}

\section{Fruit and vegetables}

Fruit and vegetables have a high nutrient density, low energy density and are an important part of a healthy, well-balanced diet. Compelling evidence suggests that diets high in fruit and vegetables have health benefits in both adults and children [20-21]. Studies among adults suggest that increased consumption of fruit and vegetables helps to reduce the increased body weight [22].

The World Health Organization, while promoting a healthy, balanced diet, recommends eating more vegetables than fruit. Vegetables should be served in the form of salads, raw or boiled, without the addition of fat, mayonnaise or roux. In this form, they retain their low energy value and high nutritional density. Fruit consumed in excessive amounts may lead to weight gain due to their relatively higher caloric content, resulting from a higher carbohydrate content compared to vegetables. Therefore, they should be consumed daily, but in the amount of 2-3 servings, where the volume of a cup of a ready-to-eat product is considered a portion [23]. The fruit portion should not be replaced with juice [24-25].

School interventions based on increasing the proportion of fruit and vegetables in the meals served to students seem most appropriate. It turns out, however, that the precise analysis of the effects of their implementation is difficult because changes in the composition of the school diet, aimed at counteracting obesity, most often include not only an increase in the amount of fruit and vegetables, but also a reduction in the fat content of meals [26].

\section{Fruit juices}

There are many reports in the American literature on the relationship between the consumption of larger amounts of juices by children and an increased incidence of overweight and obesity [26-27]. This is especially true for younger children, aged from 2 to 5 , in whom excessive consumption of juices increases the risk of overweight and obesity in the following years of life [27]. Juices, compared to 
whole fruit, contain less dietary fiber, and thus may produce less satiety and promote the intake of more calories in a shorter time [24-25]. Consumption of fruit juices can be part of a healthy, balanced diet, as long as they are consumed in small, controlled amounts.

\section{Sweetened beverages}

Consumption of sweet fizzy drinks and sweetened fruit drinks by children has increased significantly in recent decades, and this phenomenon is particularly pronounced among adolescents. They have become one of the main energy sources, and at the same time also the main source of fluid supply (sometimes exceeding $50 \%$ of their daily consumption) [26]. Simple sugars contained in beverages are an important and easily assimilated source of energy for the body and are conducive to the development of obesity [26-27].

A particular sweetener with unfavorable properties is the glucose-fructose syrup or more specifically - corn high-fructose syrup, which is a mixture of simple sugars, especially fructose. Fructose, in the past considered as an excellent substitute for table sugar, is today indicated as a causative factor in many metabolic disorders related to an inappropriate lifestyle, including obesity. It is also known from research that excess fructose in the diet stimulates de novo postprandial liver lipid synthesis, and thus contributes to dyslipidemia. The excess of this simple sugar is associated also with the increased risk of such medical conditions as insulin resistance and alterations in carbohydrate metabolism, nonalcoholic fatty liver disease or hypertension [28-29].

In a US NHANES III study, an analysis of more than 10,000 children from 2 to 19 years of age showed that overweight and obese children consumed more sweetened beverages than normal-weight children, and these findings were consistent across all the analyzed age groups [30]. Sweetened drinks belong to the group of foods with low nutritional value and high energy load, and consuming them in greater amounts increases the risk of excessive weight gain. Limiting the intake of beverages in the treatment of overweight and obesity in children seems to be a simple and yet highly effective method of reducing the amount of energy consumed [31].

\section{Dairy products and calcium}

The results of the studies analyzing the relationship between the consumption of dairy products and other sources of calcium and the risk of obesity are not fully clear, but they allow preliminary conclusions regarding their potential role in reducing this risk. Many studies have reported that reduced dietary calcium is associated with excess body fat. Calcium intake seems to be lower in overweight children than in children of normal weight, even after excluding the effect of the total amount of energy provided in the diet [26]. In turn, prospective studies conducted in groups of preschool children confirmed that chronic, controlled calcium intake is associated with a lower share of adipose tissue in body weight [16,32].

Recommending an increase of dairy products and calcium in the diet seems to be justified in obesity prevention, however the mechanism of how these elements of diet affect the regulation of body weight and their possible associations with other factors involved in this regulation remain to be clarified [26].

Low calcium levels disrupt glucose homeostasis, leading to increased insulin resistance. Calcium deficiency in the early growth period, as a factor contributing to the development of obesity, may be of importance even in adulthood and is associated with some diseases coexisting with obesity [33].

\section{Dietary fiber}

Although there are no precise standards for the fiber content, an adult diet should contain about from 18 to 38 $\mathrm{g}$ of dietary fiber daily from various sources. According to the guidelines of $\mathrm{WHO} / \mathrm{FAO}$, as little as $25 \mathrm{~g}$ of fiber a day meets the needs of the body, enabling it to function properly. As children have lower energy requirements and eat smaller meals, the amount of fiber they need to function properly is also reduced. According to the current recommendations for the Polish population, sufficient dietary fiber intake in children ranges from $10 \mathrm{~g}$ at the age of 1-3 years, through $14 \mathrm{~g}$ at the age of $4-6,16 \mathrm{~g}$ at the age of 7-9 and $19 \mathrm{~g}$ at the age of 9-15, until reaching the minimum $25 \mathrm{~g}$ of fiber at the age of 18 [23].

In the last 30-40 years, the amount of sources of carbohydrates consumed by children have increased, mainly in the form of poor-fiber white bread and other processed products of grains, vegetables with high starch and sweetened beverages. It seems that this was a significant increase in the share of the poor in fiber products in diet of children and adolescents which may be partly responsible for the observed increased incidence of obesity [26].

Foods containing large amounts of fiber are more effective in inducing satiety, and if they replace other foods, this should result in lower total energy intake [10-11]. A number of studies support the role of dietary fiber in the regulation of body weight, thus it seems reasonable to recommend the increased role of full-grain products, legumes and low-starch vegetables, as well as nuts in child nutrition. Such a diet, regardless of the effect on the increase in adipose tissue mass and reduced risk of incidence and increasing obesity, provides additional benefits in the form of the protection against cardiovascular diseases and type 2 diabetes [26].

\section{Nutritional behavior}

Obesity is associated not only with the quantity and quality of food consumed but also with certain behavioral aspects related to eating. The family environment mainly influences the child's eating behavior. The home is the most important environment in a child's life and it is the parents who have the greatest influence on their children's eating behavior. The school or pre-school environment has an additional impact through the education provided in the classroom and by offering specific meals. Eating attitudes and habits developed in childhood influence the nutrition in later years of life [34]. 


\section{Snacks}

A precise analysis of the impact of the phenomenon of eating between meals is difficult due to the lack of a clear definition of the so-called "snacks". It is considered as a situation when food is consumed in an unplanned manner, between main meals. The analyses conducted for many years have shown that in the group of children and adolescents there has been a drastic increase in the consumption of snacks with a low nutritional value, and of an increased content of fat and simple carbohydrates, and thus of a higher energy load [35]. Snacking can contribute to the development of obesity through an increased caloric intake in the diet, especially if it occurs at a time when no attention is paid to the act of eating, e.g. when watching $\mathrm{TV}$ programs or playing computer games [36].

\section{Number of meals per day}

The number of wholesome meals consumed per day is inversely proportional to the prevalence of obesity in children - its frequency decreases with the number of meals. In a study of the German population conducted in a group of 5 and 6 -year-old children, $5 \%$ of obesity cases was found in children eating 3 meals a day, $3 \%$ with 4 meals, and $2 \%$ in children consuming 5 or more meals [37]. More meals a day, distributed at moderately regular intervals, reduces the feeling of hunger, and thus also the frequency of reaching for high-calorie snacks in children.

\section{Skipping breakfast}

Numerous studies show that obese children are more likely to eat smaller breakfasts than their lean peers, or do not eat them at all [17]. Research conducted in the USA presents the phenomenon of skipping breakfast by children and adolescents as increasing - its frequency has been recently estimated at over $20 \%$. Children and teenagers who skip breakfast regularly, have a higher BMI and higher visceral fat. On the other hand, children and adolescents who regularly eat breakfast are less likely to be overweight, even if the total amount of calories consumed by them during the day is greater than in children who miss breakfast. The mechanism of this phenomenon is unclear - it seems to be partly due to the limitation of the amount of nutritious meals during the day, and also to more frequent use of readily available, and high-calorie snacks, as well as to compensatory, increased amount of calories in the afternoon and evening hours [38].

\section{Eating late in the evening}

Regardless of the reports on the effect of skipping breakfast on the increase in the prevalence of overweight and obesity, there is also evidence that a similar effect among school-aged children exerts frequent eating late in the evening [39]. However, these abnormal eating behaviors may be related to each other, constituting elements of a disturbed physiological rhythm of eating meals.

\section{Eating out}

What contributes to obesity is also eating meals outside the home, especially in fast food restaurants, where the portions of a single meal are often increased and not adapted to the energy needs of a child at a certain age [40], as well as contain large amounts of saturated fat and little dietary fiber. On the other hand, frequent consumption of meals at home, in a family circle, reduces the risk of overweight in children, probably due to a higher consumption of fruit, vegetables and milk, and lower consumption of fried products and sweet drinks [17].

\section{SUMMARY}

Numerous studies on the nutritional behavior of children and adolescents indicate a number of recurring abnormalities in both the nutritional model and the composition of the diet. Food is an indispensable element necessary for proper functioning, however, controlling the quantity and quality of consumed meals is crucial in the context of obesity prevention in developmental age. Of particular importance is the balance between the energy supply in the form of calories coming from dietary components and the energy expenditure through spontaneous and planned physical activity. Due to the fact that the taste preferences and eating habits of a child are formed from the first years of life, and are often continued into adulthood, a necessary element of obesity prevention seems to be the intensive education of parents and caregivers in the field of proper nutrition of children and in the principles of a healthy lifestyle. 


\section{Wybrane aspekty żywienia dzieci i ich znaczenie w etiologii otyłości}

\section{WPROWADZENIE}

Odpowiednio zbilansowana dieta pod względem ilościowym i jakościowym, a także dostosowanie jej do wieku i potrzeb energetycznych organizmu dziecka są kluczowe dla zapewnienia mu optymalnych warunków dla prawidłowego wzrostu i rozwoju. Zaburzenia bilansu energetycznego pomiędzy podażą, a wydatkowaniem energii, w połączeniu $z$ nieprawidłowymi zachowaniami żywieniowymi, należą do podstawowych przyczyn występowania otyłości u dzieci i młodzieży [1]. Celem pracy jest przegląd aktualnego stanu wiedzy dotyczącej wpływu modelu żywienia, składu diety oraz aspektów behawioralnych związanych z przyjmowaniem pokarmu na występowanie otyłości u dzieci i młodzieży.

\section{Karmienie niemowlat oraz wczesne kształtowanie nawyków żywieniowych}

Istnieją dowody na to, że dzieci karmione piersią mają mniejsze ryzyko rozwoju otyłości w późniejszym okresie życia, niż ich rówieśnicy karmieni mlekiem modyfikowanym [2-3]. Choć przyczyny tego zjawiska pozostają niejasne, podkreśla się istotną rolę jaką odgrywa unikalny, optymalnie dostosowany do potrzeb niemowlęcia skład mleka kobiecego. Istnieje hipoteza, iż dzieci karmione piersią kierując się uczuciem głodu i sytości same regulują ilość i objętość przyjmowanych posiłków, oraz ich porę. Ma to wpływ na lepszą kontrolę apetytu w późniejszym wieku w porównaniu do niemowląt karmionych mlekiem modyfikowanym [4]. Dzieci karmione piersią dokonują samoregulacji spożycia składników odżywczych i wykazują samokontrolę kaloryczności spożywanych posiłków [5].

Większość mieszanek na bazie modyfikowanego mleka krowiego zawiera większą ilość białka niż mleko kobiece. To zjawisko uznaje się za kluczowy czynnik sprzyjający szybszemu przyrostowi masy ciała u dzieci karmionych sztucznie, nazywane także hipotezą wczesnej podaży białka [6]. Nadmiar białka w diecie niemowlęcia, szczególnie aminokwasów rozgałęzionych przyczyniają się do nadmiernego wydzielania insuliny oraz IGF-1, aktywują szlaki sygnałowe wzrostu komórkowego mTOR i nasilają adipogenezę [7]. Badania potwierdzają, iż wczesne spożycie wysokiej ilości białka zawartej w mleku modyfikowanym skutkuje wyższym BMI w późniejszym życiu [8].

Kolejnym mechanizmem opisywanym w literaturze, mającym znaczenie w profilaktyce otyłości, jest skład mikrobioty jelitowej dzieci karmionych piersią [9]. Mleko matki stanowi źródło naturalnych prebiotyków, które stymulują wzrost bakterii kwasu mlekowego w układzie pokarmowym dziecka oraz probiotyków [10]. Kalliomäki i wsp. przeprowadzili badania, w których dowiedli iż obniżona ilość bakterii Bifidobacterium między 6-12 miesiącem życia ma związek ze zwiększoną masą ciała w wieku 7 lat [11].
Ochronny wpływ karmienia piersią przed nadmierną masą ciała ma szczególne znaczenie u dzieci pochodzących z ciąż kobiet z nadwagą i otyłością, w tej też grupie jest on najwyraźniej zaznaczony [12]. Karmienie naturalne wydaje się również wywierać wpływ ochronny i zmniejszać ryzyko wystąpienia w późniejszym okresie życia takich chorób jak: nadciśnienie, cukrzyca, czy choroby sercowo-naczyniowe [13-14].

Warto zaznaczyć, że nie tylko sam sposób karmienia niemowlęcia ma wpływ na rozwój otyłości w późniejszym wieku. Duże znaczenie ma masa ciała dziecka w pierwszym roku życia. Badania dowodzą, iż gwałtowny przyrost masy ciała w ciągu pierwszych miesięcy życia wiąże się ze znacznie zwiększonym ryzykiem otyłości w wieku młodzieńczym i dorosłym. Zmiany w masie ciała w okresie niemowlęcym mogą wpływać na ryzyko późniejszej otyłości bardziej, niż sama masa urodzeniowa [15].

Dzieci bezpośrednio po urodzeniu cechują określone preferencje smakowe, a także zdolność do regulacji ilości przyjmowanego w ciągu doby pożywienia. Działania rodziców uniemożliwiające dziecku samokontrolę w tym zakresie skutkują nie tylko zmianą upodobań smakowych dziecka, ale także zaburzeniem wrodzonych szlaków regulacji uczucia głodu i sytości i prowadzą do spożywania przez dziecko nadmiernej ilości kalorii. Uważni rodzice, kontrolujący sposób odżywiania dziecka, szczególnie jeśli jest ono obciążone rodzinnie wystąpieniem otyłości, mogą wykształcić pozytywne nawyki żywieniowe przez promowanie zdrowej diety odpowiedniej dla wieku dziecka, przy zachowaniu właściwego bilansu energetycznego [16-19].

\section{Wybrane grupy pokarmów i ich znaczenie w kontekście rozwoju otyłości}

\section{Owoce i warzywa}

Owoce i warzywa mają dużą gęstość odżywczą, małą gęstość energetyczną i są ważnym elementem zdrowej, zbilansowanej diety. Przekonujące dowody sugerują, że diety bogate w owoce i warzywa niosą ze sobą korzyści zdrowotne zarówno u dorosłych, jak i u dzieci [20-21]. Badania wśród dorosłych sugerują, że zwiększone spożycie warzyw i owoców przyczynia się do zmniejszonego nasilenia otyłości u pacjentów z nadmierna masą ciała [22].

Światowa Organizacja Zdrowia, zajmując się promowaniem zdrowej, zbilansowanej diety, poleca spożywanie większej ilości warzyw niż owoców. Warzywa powinny być podawane $\mathrm{w}$ formie surówek, sałatek czy też w postaci gotowanej, bez dodatku tłuszczu, majonezu czy zasmażki. W takiej postaci zachowują swoją małą wartość energetyczną oraz dużą gęstość odżywczą. Owoce spożywane w nadmiernych ilościach mogą doprowadzać do wzrostu masy ciała ze względu na ich relatywnie większą kaloryczność, wynikającą z większej zawartości węglowodanów 
w porównaniu z warzywami. Dlatego też powinny być spożywane codziennie, ale w ilości 2-3 porcji, przy czym za porcję uważa się objętość filiżanki gotowego do zjedzenia produktu [23]. Porcja owoców nie powinna być zastępowana sokiem [24-25].

Interwencje szkolne oparte na zwiększeniu udziału owoców i warzyw w posiłkach podawanych uczniom wydają się jak najbardziej celowe. Okazuje się jednak, że precyzyjna analiza efektów ich realizacji jest o tyle trudna, że zmiany w składzie diety szkolnej, mające na celu przeciwdziałać otyłości, najczęściej obejmują nie tylko wzrost ilości owoców i warzyw, ale również ograniczenie zawartości tłuszczu w posiłkach [26].

\section{Soki owocowe}

W piśmiennictwie amerykańskim można znaleźć wiele doniesień o związku przyjmowania przez dzieci większych ilości soków ze zwiększoną częstością występowania nadwagi i otyłości [26-27]. Dotyczy to szczególnie młodszych dzieci, w wieku 2 do 5 lat, u których nadmierne spożywanie soków zwiększa ryzyko nadwagi i otyłości w kolejnych latach życia [27]. Soki, w porównaniu do całych owoców, zawierają mniej włókna pokarmowego, a więc mogą dawać mniejsze uczucie sytości oraz promować przyjęcie większej ilości kalorii w krótszym czasie [24-25]. Spożycie soków owocowych może być elementem zdrowej, zbilansowanej diety, pod warunkiem jednak, że będą one spożywane w niewielkich, kontrolowanych ilościach.

\section{Słodzone napoje}

Spożycie przez dzieci słodkich napojów gazowanych, czy słodzonych napojów owocowych wzrosło znacząco w ciągu ostatnich dziesięcioleci, a zjawisko to jest szczególnie nasilone wśród młodzieży. Stały się one jednym z głównych źródeł dostarczanej do organizmu energii, a jednocześnie też głównym źródłem podaży płynów (niekiedy przekraczając nawet $50 \%$ ich dobowego spożycia) [26]. Zawarte w nich cukry proste są istotnym i łatwym do przyswojenia źródłem energii dla organizmu i sprzyja rozwojowi otyłości [26-27].

Szczególnym słodzikiem o niekorzystnych właściwościach jest syrop glukozowo-fruktozowy lub dokładniej wysokofruktozowy syrop kukurydziany, który jest mieszanką cukrów prostych, szczególnie fruktozy. Fruktoza, w przeszłości uznawana za doskonały zastępnik cukru stołowego dziś jest wskazywana jako czynnik sprawczy wielu zaburzeń metabolicznych związanych z niewłaściwym stylem życia, także otyłości. Z badań wiadomo również, że nadmiar fruktozy w diecie stymuluje poposiłkową syntezę lipidów de novo przez wątrobę, przyczynia się zatem do dyslipidemii. Z obserwacji wynika także, że nadmiar tego cukru prostego związany jest ze zwiększonym ryzykiem rozwoju takich chorób jak insulinooporność i zaburzenia przemian węglowodanów, niealkoholowa stłuszczeniowa choroba wątroby czy nadciśnienie tętnicze [28-29].

W przeprowadzonych w USA badaniach w ramach programu NHANES III, analiza obejmująca ponad 10 tysięcy dzieci w wieku od 2 do 19 lat wykazała większe spożycie słodzonych napojów przez dzieci z nadwagą i otyłością, niż przez dzieci z prawidłową masą ciała, a obserwacje te były spójne we wszystkich analizowanych grupach wiekowych [30]. Słodzone napoje należą do grupy środków spożywczych o małej wartości odżywczej, dużym natomiast ładunku energetycznym, a spożywanie ich w zwiększonych ilościach zwiększa ryzyko nadmiernego przyrostu masy ciała. Ograniczenie spożycia tych napojów w terapii nadwagi i otyłości u dzieci wydaje się być prostą i jednocześnie bardzo skuteczną metodą ograniczenia ilości pobieranej energii [31].

\section{Przetwory mleczne i wapń}

Wyniki badań analizujących związek pomiędzy spożywaniem przetworów mlecznych i innych źródeł wapnia, a ryzykiem rozwoju otyłości nie są w pełni jednoznaczne, pozwalają jednak wyciągnąć wstępne wnioski o ich potencjalnej roli ograniczającej to ryzyko. Wiele badań opisuje związek zmniejszonej zawartości wapnia w diecie $\mathrm{z}$ nadmierną ilością tkanki tłuszczowej. Podaż wapnia wydaje się być mniejsza wśród dzieci $\mathrm{z}$ nadwagą, niż wśród dzieci o prawidłowej masie ciała, nawet po wykluczeniu wpływu ilości całkowitej energii dostarczonej w diecie [26]. Z kolei prospektywne badania prowadzone w grupach dzieci w wieku przedszkolnym potwierdziły, że przewlekła kontrolowana podaż wapnia związana jest z mniejszym udziałem tkanki tłuszczowej w masie ciała [16,32].

Zalecanie zwiększenia udziału przetworów mlecznych i wapnia w diecie wydaje się być uzasadnione w zapobieganiu otyłości, jednak mechanizm, w jakim te elementy diety wpływają na regulację masy ciała, oraz ich potencjalne związki z innymi czynnikami uczestniczącymi w tej regulacji, wymagają jeszcze wyjaśnienia [26].

Niski poziom wapnia zaburza homeostazę glukozy, prowadząc do wzrostu insulinooporności. Niedobór wapnia w okresie wczesnego wzrostu, jako czynnik sprzyjający rozwojowi otyłości, może mieć znaczenie nawet w dorosłym życiu i wiązać się z niektórymi chorobami współistniejącymi z otyłością [33].

\section{Błonnik pokarmowy}

Choć nie ma precyzyjnych norm zapotrzebowania na błonnik, w diecie dorosłego człowieka powinno się codziennie znaleźć według różnych źródeł od około 18 do $38 \mathrm{~g}$ błonnika pokarmowego. Według wytycznych WHO/ FAO już $25 \mathrm{~g}$ błonnika pokarmowego na dobę zaspokaja potrzeby organizmu umożliwiając mu prawidłowe funkcjonowanie. Ponieważ dzieci mają mniejsze zapotrzebowanie energetyczne i przyjmują mniejsze objętościowo posiłki ilość błonnika wystarczająca do ich prawidłowego funkcjonowania także jest mniejsza. Według aktualnych zaleceń dla populacji polskiej wystarczające spożycie błonnika u dzieci wynosi od $10 \mathrm{~g} \mathrm{w}$ wieku 1-3 lat, poprzez $14 \mathrm{~g}$ w wieku 4-6, 16 g w wieku 7-9 i 19 g w wieku 9-15, aż do osiągnięcia min. $25 \mathrm{~g}$ błonnika w 18. roku życia [23].

W ciągu ostatnich 30-40 lat zwiększyła się wyraźnie ilość spożywanych przez dzieci źródeł węglowodanów, głównie w postaci ubogiego w błonnik białego pieczywa i innych produktów z przetworzonych ziaren, warzyw o dużej zawartości skrobi i dosładzanych napojów. Wydaje się, że właśnie ten istotny wzrost udziału produktów ubogich w błonnik w diecie dzieci i młodzieży może być czę- 
ściowo odpowiedzialny za obserwowany wzrost częstości występowania otyłości [26].

Pokarmy zawierające duże ilości błonnika są bardziej skuteczne w wywoływaniu uczucia sytości, a zastępując inne pokarmy powodują w efekcie mniejszy sumaryczny pobór energii [10-11]. Szereg badań potwierdza rolę błonnika w regulacji masy ciała, więc wydaje się uzasadnione zalecanie zwiększenia udziału w diecie dziecięcej produktów pełnoziarnistych, owoców, warzyw strączkowych oraz warzyw o niewielkiej zawartości skrobi, a także orzechów. Taka dieta, niezależnie od wpływu na przyrost masy tkanki tłuszczowej i zmniejszania ryzyka wystąpienia i narastania otyłości, daje dodatkowe korzyści w postaci ochrony przed chorobami układu krążenia i cukrzycą typu 2 [26].

\section{Zachowania żywieniowe}

Z występowaniem otyłości wiąże się nie tylko ilość i jakość przyjmowanego pokarmu, ale również pewne aspekty behawioralne związane $z$ jedzeniem. Główny wpływ na zachowania żywieniowe dziecka wywiera środowisko rodzinne. Dom jest najważniejszym środowiskiem życia dziecka i to rodzice w największej mierze wpływają na kształtowanie zachowań związanych z jedzeniem. Środowisko szkolne lub przedszkolne dodatkowo oddziałuje poprzez treści przekazywane na lekcjach oraz oferując określone posiłki. Postawy i przyzwyczajenia żywieniowe wykształcone w dzieciństwie mają wpływ na sposób żywienia w późniejszych latach życia [34].

\section{Przekąski}

Precyzyjna analiza wpływu zjawiska podjadania pomiędzy posiłkami jest utrudniona ze względu na brak jednoznacznej definicji dla tzw. „przekąsek”. Przyjmuje się, że dotyczy to sytuacji, kiedy pokarm spożywany jest w sposób niezaplanowany, pomiędzy głównymi posiłkami. Analizy ostatnich lat wykazały, że w grupie dzieci i młodzieży drastycznie zwiększyło się spożycie przekąsek o małej wartości odżywczej, natomiast zwiększonej zawartości tłuszczu i węglowodanów prostych, a co za tym idzie większym ładunku energetycznym [35]. Podjadanie i stosowanie przekąsek może sprzyjać rozwojowi otyłości poprzez zwiększoną podaż kalorii w diecie, szczególnie jeśli dochodzi do niego w czasie, kiedy nie przywiązuje się uwagi do aktu jedzenia np. podczas oglądania programów w telewizji czy gry na komputerze [36].

\section{Ilość posiłków w ciągu doby}

Ilość spożywanych w ciągu doby pełnowartościowych posiłków jest odwrotnie proporcjonalna do występowania otyłości u dzieci - częstość jej występowania zmniejsza się wraz z ilością posiłków. W badaniu populacji niemieckiej przeprowadzonym w grupie dzieci 5 i 6-letnich wykazano 5\% występowanie otyłości u dzieci spożywających 3 posiłki w ciągu dnia, $3 \%$ przy 4 posiłkach, a $2 \%$ u dzieci spożywających 5 lub więcej posiłków [37]. Większa ilość posiłków w ciągu doby, rozłożonych w umiarkowanie regularnych odstępach czasu redukuje uczucie głodu, a tym samym również częstość sięgania przez dzieci po wysokokaloryczne przekąski.

\section{Opuszczanie śniadania}

Liczne badania wskazują, że otyłe dzieci częściej niż ich szczupli rówieśnicy jedzą mniejsze objętościowo śniadania, lub nie jedzą ich wcale [17]. Badania prowadzone w USA prezentują zjawisko opuszczania śniadania przez dzieci i młodzież jako narastające - jego częstość szacuje się obecnie na ponad 20\%. Wśród dzieci i nastolatków regularnie opuszczających śniadania stwierdza się wyższe BMI oraz większą ilość tkanki tłuszczowej trzewnej. Z kolei dzieci i młodzież regularnie spożywające śniadania mają mniejszą skłonność do nadwagi, nawet jeśli sumaryczna ilość przyjętych przez nie w ciągu dnia kalorii jest większa, niż u dzieci opuszczających śniadanie. Mechanizm tego zjawiska pozostaje niejasny - wydaje się być częściowo związany z ograniczeniem ilości pełnowartościowych posiłków w ciągu doby, a także z częstszym korzystaniem $z$ łatwo dostępnych i wysokokalorycznych przekąsek, a także kompensacyjną, zwiększoną ilością kalorii w godzinach popołudniowych i wieczornych [38].

\section{Spożywanie posiłków późno wieczorem}

Niezależnie od doniesień o wpływie opuszczania śniadania na wzrost występowania nadwagi i otyłości, istnieją również dowody na to, że podobny wpływ wśród dzieci w wieku szkolnym wywiera częste jedzenie późno wieczorem [39], jednak te nieprawidłowe zachowania związane $z$ jedzeniem mogą być ze sobą powiązane, stanowiąc elementy zaburzonego fizjologicznego rytmu spożywania posiłków.

\section{Jedzenie poza domem}

Otyłości sprzyja również spożywanie posiłków poza domem, zwłaszcza w restauracjach typu „fast food”, gdzie często porcje pojedynczego posiłku są zwiększone i niedostosowane do zapotrzebowania energetycznego dziecka w określonym wieku [40], zawierają duże ilości tłuszczów nasyconych, a mało błonnika pokarmowego. Z drugiej strony częste spożywanie posiłków w domu, w rodzinnym gronie zmniejsza ryzyko występowania nadwagi u dzieci, zapewne w związku z większym spożyciem owoców, warzyw i mleka, mniejszym natomiast spożyciem potraw smażonych i słodkich napojów [17].

\section{PODSUMOWANIE}

Liczne badania nad zachowaniami żywieniowymi dzieci i młodzieży wskazują na szereg powtarzających się nieprawidłowości zarówno w zakresie modelu odżywiania, jak i składu diety. Jedzenie jest nieodzownym elementem koniecznym do prawidłowego funkcjonowania, jednak kontrola w zakresie ilości oraz jakości spożywanych posiłków jest kluczowa w kontekście zapobiegania otyłości w wieku rozwojowym. Szczególne znaczenie ma równowaga pomiędzy podażą energii w postaci kalorii pochodzących ze składników żywieniowych a ich wydatkowaniem poprzez spontaniczną oraz zaplanowaną aktywność fizyczną. W związku z tym, że preferencje smakowe i nawyki żywieniowe kształtują się u dziecka już od pierwszych lat i często są kontynuowane w życiu dorosłym, koniecznym elementem profilaktyki otyłości wydaje się być intensywna edukacja rodziców i opiekunów w zakresie prawidłowego żywienia dzieci oraz zasad zdrowego stylu życia. 


\section{ORCID}

Katarzyna Anna Majewska (iD https://orcid.org/0000-0002-3573-2274

Magdalena Kobylińska (D) https://orcid.org/0000-0002-3871-2412

Agata Krasińska (iD https://orcid.org/0000-0001-7308-4979

Paulina Wais (iD https://orcid.org/0000-0002-1580-5894

Andrzej Kędzia (iD https://orcid.org/0000-0001-8206-6094

\section{REFERENCES/PIŚMIENNICTWO}

1. Kumar S, Kelly A. Review of Childhood Obesity: From Epidemiology, Etiology, and Comorbidities to Clinical Assessment and Treatment. Mayo Clinic Proc. 2017;92(2): 251-265.

2. Uwaezuoke SN, Eneh Cl, Ndu IK. Relationship Between Exclusive Breastfeeding and Lower Risk of Childhood Obesity: A Narrative Review of Published Evidence. ClinMed Insights: Pediatr. 2017; 11: 1-7.

3. Yan J, Liu L, Zhu Y, et al. The association between breastfeeding and childhood obesity: a meta-analysis.BMC Public Health. 2014; 14(1): 1267.

4. Disantis KI, Collins BN, Fisher J0, Davey A. Do infants fed directly from the breast have improved appetite regulation and slower growth during early childhood compared with infants fed from a bottle? Int J Behav Nutr Phys Act. 2011; 8: 89-100.

5. Redsell SA, Edmonds B, Swift JA, et al. Systematic review of randomized controlled trials of interventions that aim to reduce the risk, either directly or indirectly, of overweight and obesity in infancy and early childhood. Matern Child Nutr. 2016; 12(1): 24-38

6. Tang M. Protein Intake during the First Two Years of Life and Its Association with Growth and Risk of Overweight. Int J Environ Res Public Health. 2018; 15(8): 1742.

7. Luque V, Closa-Monasterolo R, Escribano J, Ferré N. Early Programming by Protein Intake: The Effect of Protein on Adiposity Development and the Growth and Functionality of Vital Organs. Nutr Metab Insights. 2015; 8(Suppl 1): 49-56.

8. Koletzko B, von Kries R, Closa R, et al. European Childhood Obesity Trial Study Group. Lower protein in infant formula is associated with lower weight up to age $2 \mathrm{y}$ : a randomized clinical trial. Am J Clin Nutr. 2009; 89(6): 1836-1845.

9. Cannon AM, Kakulas F, Hepworth AR, et al. The effects of leptin on breastfeeding behaviour. Int J Environ Res Public Health. 2015; 12(10): 12340-12355.

10. Bartnicka A, Gałęcka M, Mazela J. Wpływ czynników prenatalnych i postnatalnych na mikrobiotę jelitową noworodków. Stand Med. Pediatr. 2016; 13: 165-172.

11. Kalliomäki M, Collado MC, Salminen S, Isolauri E. Early differences in fecal microbiota composition in children may predict overweight. Am J Clin Nutr. 2008; 87(3): 534538.

12. Mameli C, Mazzantini S, Zuccotti GV. Nutrition in the First 1000 Days: The Origin of Childhood Obesity. Int J Environ Res Public Health. 2016; 13(9): 838.

13. Kelishadi R, Poursafa P. A review on the genetic, environmental, and lifestyle aspects of the early-life origins of cardiovascular disease. Curr Probl Pediatr Adolesc Health Care. 2014; 44(3):54-72.

14. Pereira PF, Alfenas Rde C, Araújo RM. Does breastfeeding influence the risk of developing diabetes mellitus in children? A review of current evidence. J Pediatr (Rio J). 2014; 90(1):7-15.

15. Zheng M, Lamb KE, Grimes C, et al. Rapid weight gain during infancy and subsequent adiposity: a systematic review and meta-analysis of evidence. Obes Rev. 2018 Mar;19(3):321-332

16. Dehghan M, Akhtar-Danesh N, Merchant AT. Childhood obesity, prevalence and prevention. Nutr J. 2005; 4: 24-31.

17. Hand GA, Blair SN. Energy Flux and its Role in Obesity and Metabolic Disease. Eur Endocrinol. 2014; 10(2): 131-135.

18. Majewska KA, Kobylińska MM, Tchorzewska-Skrobich M, et al. Modyfikacje bilansu energetycznego w leczeniu otyłości u dzieci. Piel Pol. 2020; 1(75): 57-63.

19. Majewska KA, Skowrońska B, Krasińska A, et al. Znaczenie środowiska wewnątrzmacicznego i rodzinnego dla występowania otyłości u dzieci. Pol Prz Nauk Zdr. 2018;4(57):416-421.

20. Drewa A, Zorena K. Profilaktyka nadwagi i otyłości u dzieci i młodzieży w krajach europejskich. Pediatr. Endocrinol. Diabetes Metab. 2017;23(3): 152-158.

21. Nepper MJ, Chai W. Parental Views of Promoting Fruit and Vegetable Intake Among Overweight Preschoolers and School-Aged Children. Glob Qual Nurs Res. 2017; 4: 1-11.

22. Ledoux TA, Hingle MD, Baranowski T. Relationship of fruit and vegetable intake with adiposity: a systematic review. Obes Rev. 2011;12(5): e143-e150.

23. Jarosz M. (red.) Normy żywienia dla populacji polskiej. Instytut Żywności iŻywienia, Warszawa 2017.
24. Ostrowska L. Leczenie dietetyczne otyłości - wskazówki dla lekarzy praktyków. Forum Zaburzeń Metabolicznych. 2010; 1(1): 22-30.

25. Gwóźdź E, Gębczyński P. Prozdrowotne właściwości owoców, warzyw i ich przetworów. Post Fitoter. 2015; 16(4):268-271.

26. Heyman MB, Abrams SA. Fruit Juice in Infants, Children, and Adolescents: Current Recommendations. Pediatrics. 2017; 139(6): 20170967.

27. Shefferly A, Scharf RJ, DeBoer MD. Longitudinal Evaluation of $100 \%$ Fruit Juice Consumption on BMI Status in 2-5 Year-Old Children. Pediatr Obes. 2016; 11(3): 221-227.

28. Okręglicka K, Pardecki M, Jagielska A, Tyszko PZ. Metaboliczne efekty nadmiernego spożycia fruktozy z dietą. Med. Og Nauk Zdr. 2017; 23(3): 165-170.

29. Morgan RE. Does consumption of high-fructose corn syrup beverages cause obesity in children? Pediatr Obes. 2013; 8(4): 249-54.

30. Troiano RP, Briefel RR, Carroll MD, Bialostosky K. Energy and fat intakes of children and adolescents in the United States: data from the national health and nutrition examination surveys. Am J Clinic Nutr. 2000; 72(5): 1343-1353.

31. Bucher Della Torre S, Keller A, Laure Depeyre J, et al. Sugar-Sweetened Beverages and Obesity Risk in Children and Adolescents: A Systematic Analysis on How Methodological Quality May Influence Conclusions. J Acad Nutr Diet. 2016; 116(4): 638-59.

32. Nappo A, Sparano S, Intemann T, i wsp. Dietary calcium intake and adiposity in children and adolescents: Cross-sectional and longitudinal results from IDEFICS/I. Family cohort. Nutr Metab Cardiovasc Dis. 2019; 29(5): 440-449.

33. Marotte C, Bryk G, Gonzales Chaves MM, et al. Low dietary calcium and obesity: A comparative study in genetically obese and normal rats during early growth. Eur J Nutr. 2014; 53(3): 769-778.

34. Decyk-Chęcel A. Zwyczaje żywieniowe dzieci i młodzieży. Probl Hig Epidem.2017; 98(2): 103-109.

35. Larson M, Story M. A review of snacking patterns among children and adolescents: what are the implications of snacking for weight status? Child Obes. 2013; 9(2):10415.

36. Bellisle F. Meals and snacking, diet quality and energy balance. Physiol Behav. 2014; 134: 38-43.

37. Toschke AM, Thorsteindottir KH, von Kries R, GME Study Group. Meal frequency, breakfast consumption and childhood obesity. Intl J Pediatr Obes.2009; 4(4): 242248.

38. Alexander KE, Ventura EE, Spruijt-Metz D, et al. Association of breakfast skipping with visceral fat and insulin indices in overweight Latino Youth. Obesity (Silver Spring). 2009; 17(8): 1528-1533.

39. Miller AL, Lumeng JC, LeBourgeois MK. Sleep patterns and obesity in childhood. Curr Opin Endocrinol Diabetes Obes. 2015; 22(1): 41-47.

40. Kupczak-Wiśniowska B, Borgosz J, Podsiadło B i wsp: Otyłość u dzieci - problem współczesnego społeczeństwa. Pielęgniarstwo XXI wieku. 2017; 1(58): 44-50.

Manuscript received/Praca zgłoszona do czasopisma: 27.07.2020

Manuscript accepted/Praca zaakceptowana do druku: 10.09 .2020

Translation/Tłumaczenie: Katarzyna A. Majewska 